\title{
Study on Dividend Distribution policy of Listed Companies in China--Takes the Coal Enterprises as an Example
}

\author{
Jihui Sun ${ }^{1, a^{*}}$ and Tingting $\mathrm{Li}^{1, \mathrm{~b}}$ \\ ${ }^{1}$ School of Economics and Management, Dalian University, Dalian, China \\ adlsunjihui@163.com, b2654185834@qq.com
}

Keywords: Dividend policy; Coal listed companies; Characteristics; Suggestions

\begin{abstract}
The dividend policy has been one of the hot issues in academic research. As one of the three core financial management decisions, dividend policy is of great significance to the growth and development of enterprises. Based on China's 37 coal listed companies as samples, the relevant data with 2010-2015 equity dividends, analysis the characteristics of coal listed company's dividend distribution policy in China and its influence factors, and puts forward some suggestions to optimize the coal listed companies dividend policy.
\end{abstract}

\section{Introduction}

As a long-term incentive mechanism that can reduce principal-agent costs, improve corporate performance and optimize the structure of human capital, equity incentive has been widely and effectively applied in western countries. [1] However, China's equity incentive started relatively late. Listed company's cash dividend is not stable, high cash dividends and earnings are not present phenomenon coexist, dividend policy's role in the protection of small and medium-sized investors' benefit is not significant. [2] As one of the world's three largest energy coal occupies a pivotal position in the energy consumption structure, accounted for about $70 \%$, the impetus to the development of the secondary industry in China. China's coal industry has experienced great change in 2002-2012, great development of the "golden decade", but since November 14, 2012, coal companies began to gradually heat down, and even some into red. Hope that through this study, coal companies can develop a more reasonable dividend policy to help guide the further development of China's capital market.

\section{Characteristics of Dividend Distribution Policy of Coal Listed Companies in China}

Firstly, dividend payment diversification, mainly cash dividends. Shares of the company in the form of dividend generally includes cash dividends, stock dividends, property dividends, debt dividend. Can be seen from table 1, 2010-2015, six years of coal the dividend distribution of listed companies to present the characteristics of diversified: cash bonuses, sent shares of stock, and combination of each other has appeared. It is not hard to see, in addition to 2015 every other year, the proportion of cash dividends are above 55\%. Is mainly due to the high proportion of state-owned shares in most of the coal listed companies in China, although the coal the state-owned shares of listed companies has been part of restricted stock circulation is achieved, but still get $5 \%$ increase or decrease must notice within six months, may not reverse trading, and many other restrictions. Therefore, the state-owned shareholders prefer cash dividend rather than stock dividend.

Secondly, cash dividend payout level is not high, early high cash flow phenomenon eased. At the end of 2000, China Securities Regulatory Commission (CSRC) is put forward in order to standardize the rights of listed companies cash dividends as the essential condition of the listed companies financing, many investors in listed companies in order to qualify as a rights issue to send now, the status of the coal enterprises also in pies now, such as 2005 Shenhuo shares for every 10 shares dividend as much as 15 yuan. As you can see from table 2, Fig. 1, a maximum of dividend 
per share in decreasing year by year, the phenomenon of high cash dividend eased. The average dividend per share is small and decreasing year by year, the average dividend per share in 2015 fell to 0.0575 yuan per share. Visible in the second half of 2012, the coal industry began to gradually decline from the profit model. Thirdly, Companies that allocate dividends are more than those who do not. Fig. 1 can be seen in addition to 2015 , the proportion of dividends paid companies are above $50 \%$. The president of Chinese Coal Association Wang Xianzheng said that 10 months of 2015, the national scale coal enterprises profit fell $62 \%$, industry losses reached more than $80 \%$, the state-owned coal enterprises by the overall to a profit of 30 billion yuan in 2014 to 22 billion 300 million yuan loss in 2015.[4]

Table 1 Form of Dividend Distribution(2010-2015)

\begin{tabular}{|c|c|c|c|c|c|c|}
\hline Form & $2010(\%)$ & $\begin{array}{c}2011( \\
\%)\end{array}$ & $\begin{array}{c}2012( \\
\%)\end{array}$ & $\begin{array}{c}2013( \\
\%)\end{array}$ & $\begin{array}{c}2014( \\
\%)\end{array}$ & $\begin{array}{c}2015( \\
\%)\end{array}$ \\
\hline Cash & 50 & 62.86 & 62.86 & 63.89 & 56.76 & 29.73 \\
\hline Cash+Stock & 5.88 & 2.86 & 2.86 & & 2.70 & \\
\hline Cash+Stock & & 5.72 & 8.58 & 2.78 & 5.41 & \\
\hline $\begin{array}{c}\text { Cash+Stock+ } \\
\text { Conversion }\end{array}$ & 8.82 & 2.86 & 2.86 & & & 2.7 \\
\hline Conversion & & 2.86 & & & 2.70 & 5.41 \\
\hline No Dividend & 35.3 & 22.84 & 22.84 & 33.33 & 32.43 & 62.16 \\
\hline
\end{tabular}

Table 2 Dividend Distribution Per Share

\begin{tabular}{|c|c|c|c|c|c|c|}
\hline Per Share (yuan) & 2010 & 2011 & 2012 & 2013 & 2014 & 2015 \\
\hline Max & 1 & 0.9 & 0.96 & 0.91 & 0.74 & 0.32 \\
\hline Min & 0.00787 & 0.03 & 0.012 & 0.005 & 0.003 & 0.002 \\
\hline Mean & 0.3696 & 0.2963 & 0.2468 & 0.1431 & 0.0734 & 0.0575 \\
\hline
\end{tabular}

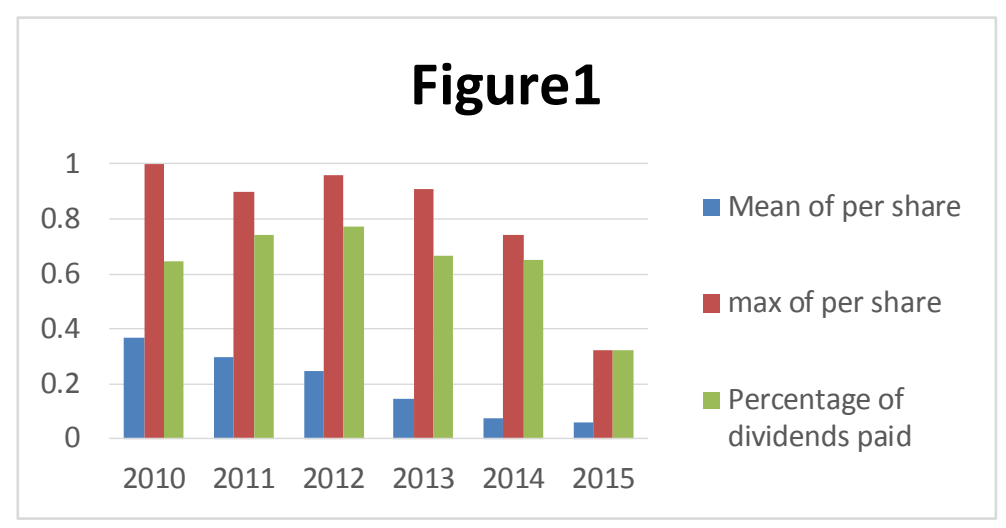

Lastly, the relative lack of continuous stability. Table 3 shows that the proportion of companies with continuous uninterrupted dividend policy is smaller. It shows that the dividend distribution policy of coal enterprises lacks long-term plan, which leads to the blindness of investors' prediction to the future.

Table 3 Continuity of Dividend Distribution

\begin{tabular}{|c|c|c|c|c|}
\hline Continuity & 3 consecutive years & 4 consecutive years & 5 consecutive years & 6 consecutive years \\
\hline Number & 4 & 4 & 5 & 11 \\
\hline Percent & 10.8 & 10.8 & 13.5 & 29.7 \\
\hline
\end{tabular}




\section{The Influence Factors of Dividend Distribution Policy}

External Factors. 1. The laws and regulations factors. The dividend policy should be on the premise of abide by relevant laws. Starting in 2001 launched "half a mandatory dividend policy", namely the refinancing qualifications linked to the level of dividend distribution. The CSRC and have released the dividend distribution rules, gradually systemized and standardized. 2 . The investor relations. The expectation of dividend distribution is different and the focus is different. Aggressive investors hope to obtain a higher percentage of stock dividend and transfer of reserve, in order to obtain premium income. Steady investors want the company to provide stable cash dividends. The state-owned shareholders mentioned above tend to cash dividends rather than stock dividends.

Internal Factors. 1. Profitability. From 2015 data, the net profit of the cash dividend of 11 coal listed companies are positive, the loss of coal enterprises basically choose no dividend. Profitability is the basis of dividend, the profitability of listed companies to a large extent determine the amount of dividend distribution. Dividend distribution level is positively correlated with profitability. 2 . Solvency. The listed companies of coal should make reasonable dividend distribution policy on the basis of reasonably evaluating the amount and period of liabilities, and avoid affecting the legitimate rights and interests of creditors due to improper dividend policy. 3. Ability to raise funds .Large scale, good efficiency of the company will be recognized by banks and financial institutions, relatively easy to raise funds. High risk, poor efficiency of enterprises to raise funds is relatively difficult, need to retain a certain surplus for the company to run. 4. The equity structure. At present, the shares of Listed Companies in China are divided into tradable shares and no tradable shares. Different shareholder's attention is not unified, often lead to the lack of common interests of the dividend distribution policy guidance. Most of China's coal listed companies are state-owned holding enterprises. State-owned corporate shares "single dominant" ownership structure seriously hindered the flow of funds and the optimal allocation of resources, is the cause of the irrational dividend policy incentives.

\section{Countermeasures and Suggestions}

Improve the Relevant Laws and Regulations on Dividend Distribution Policy. With the transformation and upgrading of economy, our country capital market in the phase of steady development, but the relevant laws and regulations are still not perfect, regulatory deficiencies. In order to maintain a fair market environment and promote the healthy development of the capital market, we need to further improve the relevant laws and regulations. By improving the securities law, the tax law, the company law and other relevant laws and regulations, reduce the probability of abnormal cash dividend behavior of listed companies. [5]

Improve the Financial Management Level. The coal industry should improve the financial management level, realize the important role of signal transfer of dividend policy, formulate a reasonable dividend policy, both to protect the majority of the interests of shareholders, also improve the dividend payment rate and the distribution of the phenomenon of instability. [6] manager is the core of a company's development and direction, usually successful enterprise is inseparable from successful managers to guide.

Improve the Profitability of the Company. In 2014, the coal industry spent a year of suffering. In 2015 influenced by the international and domestic economy, the coal market is still difficult, the coal overcapacity difficult to digest, the slowdown in demand, domestic coal prices plummeted, most coal enterprises began to live a borrowed life. December 30, 2015, the Bohai thermal coal price index closed at 372 yuan / ton, compared with the historical high of 853 yuan/ton.in November 9 , down by $56.39 \%$. However, [7] coal listed companies are still to be discovered the profitability of their own, cannot stay in the current situation, the vast majority of enterprises should also strive to find new profit growth point. For example, build information sharing platform, expand marketing channels. In highly developed Internet today, put forward the concept of Internet plus has 
injected new vitality and opportunities for the development of enterprises, coal enterprises can use coal electricity providers to increase coal sales. [8]

Broaden the Financing Channels. Capital market is not perfect, is the main reason for forming a single financing channel of listed companies, but also makes the cost of the various financing methods in the market imbalance. [9] today, the financing channels of coal enterprises mainly from banks, short-term behavior is more obvious. hence, in the process optimization of capital chain, coal enterprises should balance the financing cost of different ways of financing, improve the debt structure is unreasonable.

Accelerate the Optimization of Ownership Structure. Some behaviors of state shareholders can damage the interests of minority shareholders to a certain extent. Need to regulate the dividend policy of listed coal companies, and actively promote the share reform strategies, optimize the equity structure. In addition, to promote the implementation of preferred stock, corporate governance structure model will inevitably follow innovation, for resolving conflicts between large and medium shareholders more feasible. [10]

Perfect the Information Disclosure. To strengthen the transparency of information disclosure, one can regulate the behavior of listed companies, cut off the false opportunity together with the organization; on the other hand can maximize avoid investors because of information asymmetry caused by investment losses, let all investors stand on the same starting line to compete. Through information disclosure to reduce investors questioned the subsequent development of coal listed companies.

\section{References}

[1] Chen Wenqiang, Jia Shenghua. Equity incentive, agency cost and firm performance: an analytical framework based on dual principal agent problem [J] contemporary economic science, 2015, 02: 106-113

[2] Power making. Share splitting institutional change, equity incentive and cash dividend: Empirical Evidence from state owned listed companies [J]. Journal of Shanghai University of Finance and Economics, 2012 (14): 48-55.

[3] Chen Litai, Yang Xinfeng, Lin Chuan. Study on the impact of industry characteristics on cash dividend distribution of Listed Companies in China $[\mathrm{J}]$. technology economics, 2011,01:116-121. http://www.sxcoal.com/

[4] Tian Xiao. The dividend policy of tax [J]. economic research, 2014, 02: 90-95

[5] Zhou Feng. Dividend policy and investment value of 100 million shares of listed companies: Based on the perspective of dividend distribution of 100 million shares of listed companies [J]. accounting friends, 2013 (8): 59-63. http://www.eastmoney.com/

[6] Zhu Lin. Development dilemma and Countermeasures of coal enterprises in Shanxi province [J]. economist, 2016, 05: 16-17.

[7] Wei Wei, Zhou Xiaobo. Capital structure, ownership property and cash dividend distribution -Shanghai economic research, empirical research on the panel data of the listed company based on [J]. 2014, 04: 67-76.

[8] A Lujing. Effect of corporate governance structure on the cash dividend distribution of 2015, 05: 43-51. [J]. Economist. 